\title{
New Governors Identified in Arabic Papyri
}

\author{
Khaled Younes
}

Historical accounts record ninety-eight governors who ruled Egypt successively under the caliphs of Medina, Damascus and Baghdad up to the time of Ibn Țülūn who established an independent dynasty in $254 \mathrm{AH} / 868 \mathrm{CE}$. The $^{1}$ large number of appointments suggests a complicated administrative machinery in early Islamic Egypt. This is particularly evident when we compare the literary accounts with early documentary evidence. The narrative accounts describe that the caliph appointed the governor simultaneously over al-salāh wa-l-kharāj, i.e. the religious management of the Muslim community and the financial administration of the province. In other words, he stood at the head of the administrative hierarchy. His residence was in Fustạat and his jurisdiction extended over the whole province. The governor (Ar. wālì or amìr; Gr. symboulos) was in charge of maintaining law and order and of leading the prayers on Fridays in the great mosque in Fusțāt, a duty he was fulfilling in the absence of the caliph. ${ }^{2}$ However, according to al-Kindì's Book of the Governors, 'Anbasa b. Ishāq (in office $23^{8-242} / 85^{2-856}$ ) was the last governor to lead the prayer in the great mosque personally. ${ }^{3}$ The governor was also directly responsible for the fiscal administration of the province. From late Umayyad times, however, a separate șăhib al-kharāj was appointed by the caliph. ${ }^{4}$ This separate fiscal administration inevitably weakened the position of the governor since an important part of the province's administration was removed from his control. ${ }^{5}$ Although the governor was again fulfilling both roles in the early

1 Stanley Lane-Poole, History of Egypt in the Middle Ages (London: Methuen, 1925), 24.

2 Hugh Kennedy, "Central Government and Provincial Élites in the Early 'Abbasid Caliphate," Bulletin of the School of Oriental and African Studies 44 (1981): 28; Hugh Kennedy, "Egypt as a Province in the Islamic Caliphate," in The Cambridge History of Egypt I: Islamic Egypt 6401517, ed. Carl Petry (Cambridge: Cambridge University Press, 1998), 65; Petra M. Sijpesteijn, "New Rule over Old Structures: Egypt after the Muslim Conquest," in Regime Change in the Ancient Near East and Egypt: From Sargon of Agade to the Seljuks, ed. Harriet Crawford (London: British Academy, 2007), 184; Clive Foss, "Egypt under Mu'āwiya, part I: Flavius Papas and Upper Egypt," Bulletin of the School of Oriental and African Studies 72 (2009): 2.

3 Muhammad b. Yūsuf al-Kindī, Kitāb al-wulāt wa-kitāb al-quḍāt, ed. Rhuvon Guest as: The Governors and Judges of Egypt (Leiden: Brill, 1912), 202.

4 Kennedy, "Central Government," 33.

5 Kennedy, 35.

(C) THE AUTHOR, 2019 | DOI:10.1163/9789004386549_003

This is an open access chapter distributed under the terms of the CC-BY-NC 4.o license 
'Abbasid period, in 141/759 the governor Muhammad b. al-Ashath (in office 141-142/759-76o) refused to give a guarantee for the required sum of taxes that was to be sent to the caliphal administration in Baghdad. The caliph al-Manșūr (r. 136-158/754-775) then appointed Nawfal b. al-Furāt (in office 141-143/758761 ) in charge of the fiscal administration. Thereafter the financial affairs of the province were run by separate officials again. ${ }^{6}$ This, in turn, leads us to important questions about the division of authorities and duties between the two positions. Who was responsible for the actual management of the province and the appointment of officials at lower levels of the administration, the head of the treasury or the governor? Who was in charge of the security and stability of the province? We should bear in mind that, until the rise of the Tulunids, most of the rebellions and disturbances in the province were partly if not all tax-related. These questions can only be answered by comparing the available narrative sources with documentary evidence. This paper studies the authority of a number of persons attested in papyri whom the literary sources call financial directors. The discussed documents shed light on various aspects of the separation of power between the financial director and the governor. As we will see, some so-called financial directors may actually have been governors in practice.

The oldest and most reliable historian dealing with the administrative history of early Islamic Egypt is al-Kindì (d. 350/961), who listed all the governors of Egypt from the arrival of the Muslims in the province up to his own death date. Al-Kindī produced exact dates of appointment and dismissal, and also of entry and departure from Egypt for almost every single governor. He usually mentions whether the governor fulfilled both roles, i.e. including the fiscal administration, or was only appointed 'alā al-şalāh. Later historians such as al-Ṭabarī (d. 310/922), al-Jahshiyārī (d. 331/942), Ibn Taghrī Birdī (d. 874/1470) and al-Maqrīzī (d. 845/1442) relied mainly on al-Kindī's accounts, in addition to some other sources including archival materials. Nevertheless, considerable discrepancies in dates and names are recorded when comparing the various types of literary and documentary sources, especially in the Abbasid era. A large reservoir of documentary sources including papyri, but also weights and measures mention governors who lack from al-Kindî's account. In what follows I shall present three papyri, which mention two such unknown governors: Huwayy b. Huwayy (in office 181-182/797-798) and Muhammad b. Sa īd (in

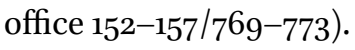

6 Kennedy, 33. 


\section{$1 \quad$ Letter Reporting on the Appointment of Huwayy b. Huwayy}

Fusțāṭ

$32 \times 29 \mathrm{~cm}$

P.Ryl.Arab B II 10 recto

3rd Ramaḍān 181/ 29th October 797

Pl. 1

Dark brown papyrus which is getting darker at the bottom. The text is written in black ink with a medium-thick pen by a clear hand in 22 lines accross the fibers. The letter is incomplete at the bottom where an unknown number of lines are missing. Similarly, the top left corner is lost resulting in a loss of three lines. There are also several holes and lacunae in different places of the papyrus which have caused damage to the text. The original cutting lines have been preserved on the right hand side and partially on the left hand side. The verso contains another letter written in a different hand. ${ }^{7}$ The papyrus sheet has been folded nine times horizontally, but there are no vertical folds perceptible. There are very few diacritical dots. The provenance of this papyrus is unknown, but I suggest it was written in Fustạt since it reports on the latest news in the city.

This letter was first published in P.Ryl.Arab. I, pp. 3-5, without a photograph. Adolf Grohmann was able to eliminate some of the numerous mistakes of the editio princeps in his subsequent publication (P.World, pp. 171-173). After examining the original papyrus and with the aid of a photograph I was able to read much more of the letter and correct previous editions in a number of places.

$1.1 \quad$ Text

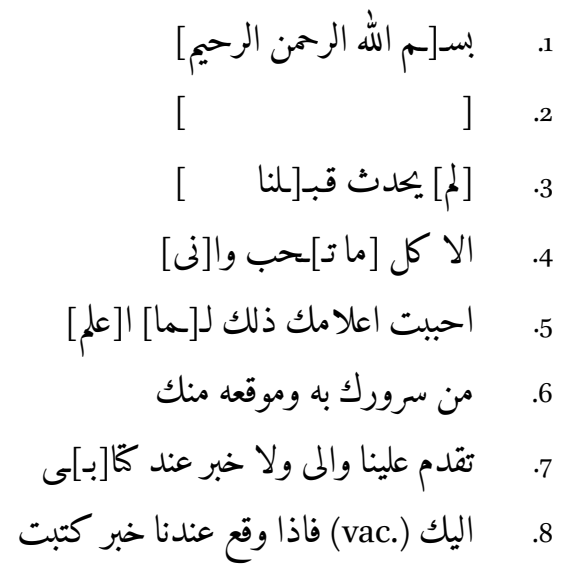

7 P.Ryl.Arab. I, pp. 221-222. 


$$
\begin{aligned}
& \text { 9. به اليك سريعا ان شا الله والقمح عندنا }
\end{aligned}
$$

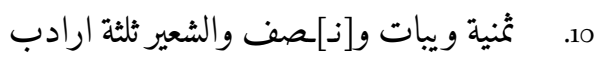

$$
\begin{aligned}
& \text { 11. وان المزا|رعين عندنا قد وضعوا ايديهـ[م] }
\end{aligned}
$$

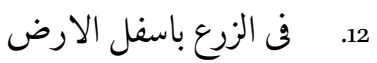

$$
\begin{aligned}
& \text { 13. وان عمال الكور قد تسجلوا لمم وان ابن[ت]ـى } \\
& \text { 14. قد دخلت على زوجها (vac. } \\
& \text { (vac.) }
\end{aligned}
$$

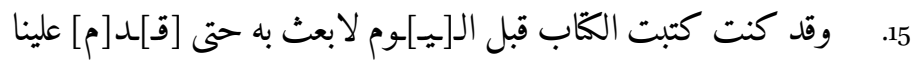

$$
\begin{aligned}
& \text { 16. ولاية حوى بن حوى على الصلاة والخراج (vac.) } \\
& \text { 17. وقد ولى بن فليح الزمام والـ[خ]ـراج وابى عبيدة } \\
& \text { 18. .ن عقبة بن نافع على الصع[ي_]د والخراج وقد كتب حوى ساده (؟) }
\end{aligned}
$$

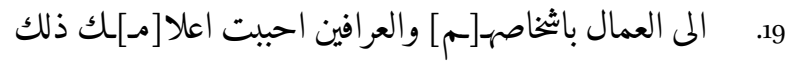

$$
\begin{aligned}
& \text { 20. لتكون منه على علم واناقرت ولايته يوم الاحد } \\
& \text { 21. لثلث خلون من رمضان ولم يكون عندنا بعد خبـ[ـ] نكتب به به } \\
& \text { 22. اليك وقد نقلت التوابيت والدواوين ا[ل]ـى }
\end{aligned}
$$

1.2 Diacritical Dots

$$
\text { 9) ان 13) (بنتى 14) زوحها 16) الصلاة 22) اليك؛ نعلت }
$$

\subsection{Translation}

1. In the [name of God, the Compassionate, the Merciful]

2. [

3. [Nothing] happened to [us

4. $\quad$ except what pleases you and [I]

5. have thought it proper to inform you of this, because I know

6. your delight in it and the pleasure it gives you.

7. A new governor ( $w \bar{a} \bar{l} \bar{\imath})$ has been appointed and I have no news to write

8. to you. (vac.) And if we get any news, I will write

9. it to you promptly, if God wills. Wheat here is

10. eight waybas and a half and the barley is three irdabbs.

11. And the peasants have put their hands 
12. on the crops in Lower Egypt.

13. And the officials of the districts have registered for them. And my daughter

14. has cohabited with her husband. (vac.) (vac.)

15. I (already) wrote this letter before today (with the intention) to send it, when we learned of

16. the appointment of Huwayy ibn Huwayy over prayer and finances. (vac.)

17. And he appointed Ibn Falīh over the control of the dīwāns (al-zimām) and the finances and Abī 'Ubayda

18. ibn 'Uqba ibn Nāfi' over Upper Egypt and the finances. And Huwayy has written ...

19. to the officials and the tribal heads summoning them. I have thought it proper to inform you of this

20. that you might be aware of it. His appointment was only confirmed on Sunday

21. when three nights had passed of Ramadān. We have no more news after this to write

22. to you. And the tawābìt and the dawāwin have been transferred [t $]_{\mathrm{o}}$

\subsection{Commentary}

1. Of the basmala only the $b \vec{a}$ and $\sin$ of bism are still visible at the top right corner.

2-4. Due to the top left corner being lost, only traces of letters and words can be read at the beginning of these three lines. The expression lam yahduth qiba[lanā] illa kull [mā tu] hibb is reconstructed on the basis of parallels. ${ }^{8}$

5-6. ạ̣babbtu itāmuka dhälika li $[\mathrm{ma}]$ a ['lamu] min surūrika bihi wa-mawqi ihi minka. This formula is attested in exactly the same form in P.Marchands I 35.5-6; P.Marchands $\mathrm{v} / 1$ 20.1-2, both third/ninth century and coming from the Fayyūm.

7. taqadama 'alaynā wālì. For the title wālì in the papyri, see qad ja'alaka Allāh wāliyanā wa-l-wālì huwa li-ra'îyatihi, Yusūf Rāgib, "Lettres Arabes I," Annales Islamologiques 14 (1978), 15-35, 5.4-5, (third/ninth century); wālì Aträbulus, P.Khalili I 6.11-12 (third/ninth century), but see also, Werner Diem, "Philologisches zu den Khalili-Papyri I," Wiener Zeitschrift für die Kunde des Morgenlandes 83 (1993), 39-81, 42.

8 Cf. Khaled Younes, "Joy and Sorrow in Early Muslim Egypt: Arabic Papyrus Letters: Text and Context" (PhD diss., Leiden University 2013), 8.4-5 (second/eighth century) and the commentary. 
7-8. wa-lā khabar 'inda kitā [b] ìilayka. A short space has been left blank after ilayka. Kitābi is written with a long space between the alif and $b \bar{a}$, while the $y \vec{a}$ returns horizontally backwards to cover the space.

8-9. fa-idhà waqa'a 'indanā khabar katabtu bihi ilayka sarīan in shāa Allāh. There is one ink spot under the $r \vec{a}$ of sarīan that could be mistaken for diacritics.

9-10. wa-l-qamh 'indanā thamāniya waybāt wa-[n]iss wa-l-sha'ìr thalātha arādibb. In his edition Grohmann claims that the amounts of wheat and the barley given here indicate the fixed price of each commodity in the market. He goes even further by arguing that the numbers refer to dirhams, meaning a pretty low price. Grohmann therefore praises the letter for its "special interest for Egypt's economy as well as for the history of Egypt's administration". ${ }^{9} \mathrm{~A}$ simpler and more realistic explanation in my view, however, is that the sender informs the addressee of what remains of wheat and barley using commodities they are both familiar with.

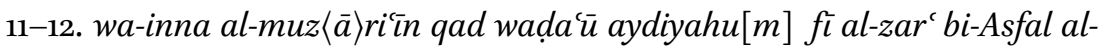
Ard. The scribe left the medial alif of al-muzāricin out. The idiom Asfal al-Ard is used in both the narrative and documentary sources for Lower Egypt or the Delta. See Adolf Grohmann, Studien zur historischen Geographie und Verwaltung des mittelalterlichen Ägypten (Vienna: Rudolf M. Rohrer 1959), 25-26; Yūsuf Rāgib, "Sauf-Conduits d'Égypte Omeyyade et Abbasside," Annales Islamologiques 31 (1997): 148.

13. wa-inna ummālal-kuwar qad tasajjatū lahum. The title 'ämil (pl. 'ummāl) occurs frequently in papyri. From the early second/eighth century onwards the 'ummāl appear as the officials issuing tax receipts and safe conducts (Cf. Petra M. Sijpesteijn, Shaping a Muslim State: The World of a Mid-Eighth-Century Egyptian Official (Oxford: Oxford University Press, 2013), 14.22, second/eighth century and the commentary; Gladys Frantz-Murphy, Arabic Agricultural Leases and Tax Receipts from Egypt. Corpus Papyrorum Raineri XxI (Wien: Hollinek, 2001), 118). For kūra (pl. kuwar), see Grohmann, Historischen Geographie, 34. For the verb tasajjala, referring to fiscal register, see Frantz-Murphy, Arabic Agricultural Leases, 111-113; Geoffrey Khan, Arabic Papyri: Selected Material from the Khalili Collection, Studies in the Khalili Collection 1 (London/Oxford: Nour Foundation in association with Azimuth Editions, Oxford University Press, 1992), 61-65, esp. 64 .

13-14. wa-inna ibna[t]̄̇ qad dakhalat 'alā zawjihāa. Mixing private news with commercial and administrative affairs is common in letters from early Islamic

9 Adolf Grohmann, From the World of Arabic Papyri (Cairo: Dār al-Macārif Press, 1952), 173. 
Egypt. For similar expressions, cf. wa-qad kuntu bi-l-Fusțāt hattā qadima zawj bintī fadakhala 'alayhā, Chrest.Khoury I, 98 (second/eighth century). See also Younes, Joy and Sorrow, 38-39.

15. wa-qad kuntu katabtu al-kitāb qabl al-[y]awm li-ab'ath bihi hattāa $[q]$ adi$[m] a$ 'alayna $\bar{a}$. The construction qad + kāna followed by an imperfect should be translated as past perfect (Simon Hopkins, Studies in the Grammar of Early Arabic: Based upon Papyri Datable to Before 30oA.H./912 A.D. (Oxford: Oxford University Press, 1984), § 239).

16. For wilāyat Huwayy ibn Huwwayy 'alā al-ṣalāh wa-l-kharāj, see the discussion below.

17-18. wa-qad wallā Ibn Falīh al-zimām wa-l-[kh]arāj wa Abì 'Ubayda ibn 'Uqba ibn Näfi' 'alā al-Ṣac [ī]d wa-l-kharāj. For the full indentification of Ibn Falịh and Abū 'Ubayda b. 'Uqba b. Nāfi', see the discussion below.

18. I was not able to find a satisfactory reading for the last word in this line. I read two denticles, an alif, a dāl or dhāl and a $h \bar{a}$ or $t \bar{a}$ marbüța. Margoliouth reads this word as kitäbahu which does not fit the rasm.

18-19. wa-qad kataba Hưwayy ... ilā al-'ummāl bi-ishkhāṣihim wa-l-'arrāfin. Margoliouth reads wa-l-arräfin as min al-Irāqayn meaning from the two Iraqs, i.e. Kūfa and Bașra, which does not make sense. For the 'arîf, see Sobhi Bouderbala, "Ǧund Miṣr:Étude de l' Administration Militaire dans l' Égypte des Débuts de l'Islam 21/642-218/833" (PhD diss., Université de Paris 1-Panthéon-Sorbonne, 2008), 261-268.

19-20. ahbabtu i'āā $[m]$ uka dhālika li-takūna minhu 'alā 'ilm. For similar expressions, see ahbabtu i'tāmuka dhālika li-taqifa 'alayhi in P.Hamb.Arab. II 1v5-6, (second/eighth century). See also above lines $5^{-6}$.

20-21. wa-innamā qarrat wilāyatuhu yawm al-ahad li-thaläth khalawna min Ramadān. On dating formulae using a form of the verb khalawna, see Adolf Grohmann, Arabische Chronologie: Arabische Papyruskunde (Leiden: Brill, 1966), 19-20. The ink is smudged in yawm al-ahad.

21-22. wa-lam yakūn 'indanā ba'd khaba[r] naktubu bihi ilayka. The long vowel is maintained in the jussive, wa-lam yakūn, where Classical Arabic requires a short vowel (Hopkins, Grammar of Early Arabic, § 81.a).

22. wa-qad nuqilat al-tawābìt wa-l-dawāwìn i[lā]. Tābūt (pl. tawābìt) is not a sort of police or bodyguard as Margoliouth put it, nor a water-wheel as Grohmann suggested, but a chest. Al-Kindī in two instances mentions that persons were appointed 'alā al-tābūt, "over the tābūt" as if it were an institution. ${ }^{10}$ Elsewhere, however, al-Kindī writes about a tābüt, "chest", of the chief 
$q \bar{a} d \underline{\imath} \bar{\imath}$ of Egypt in the central treasury in which the money for the orphans was stored in ca. $801 \mathrm{CE} .{ }^{11} \mathrm{He}$ also writes about a locked tābüt in the central treasury possibly related to pious foundations in ca. $841 \mathrm{CE} .{ }^{12} \mathrm{Ibn}$ 'Abd al-Hakam also mentions that 'Umar b. al-Khatțāb stored conquest treaties in a tābūt. ${ }^{13}$ There is no doubt that the administrative archives and central treasury made use of chests to store documents and money. The document's administrative nature suggests these were chests containing documents or money in the archives or treasury. The unpublished papyrus P.Cam.Michaelides C 1096 refers to a similar chest. The document records a number of leather products taken from the tābüt in the years $261-262 / 875^{-876}$ to be delivered to a certain Abū Zakarīya. Transferring dīwa ans is recorded in narrative sources to refer to the actual transfer of power from one governor/financial director to the other. The financial director Nawfal b. al-Furāt (in office 141-143/758-761) transferred the dīwāns to dār al-ramlafter the refusal of the governor Muhammad b. al-Ash'ath (in office 141-142/759-76o) to give a guarantee for the required sum of taxes to the central administration..$^{14}$

A Decree Issued in the Name of the amir Huwayy b. Huwayy ${ }^{15}$

Fayyūm ${ }^{16}$

$4.7 \times 11.3 \mathrm{~cm}$

P.UCL Petrie Ars. inv. $6 \mathrm{o}^{17}$

$182 / 797$

Pl. 2

Light brown papyrus written in black ink with a medium-thick pen accross the fibers by a skilled and experienced hand. The papyrus was cut on the right and left hand sides resulting in a considerable loss of text. There are also small lacunae at the bottom that have caused damage to the text. The original cutting

\footnotetext{
11 al-Kindī, 405.

12 al-Kindī, 45o.

13 'Abd al-Raḥmān b. 'Abd Allāh b. 'Abd al-Ḥakam, Futūḥ Miṣr wa-akhbāruhā, ed. Charles Torrey as: The History of the Conquests of Egypt (Leiden: Brill, 1920), 89.

14 al-Kindī, al-Wulät, 109 .

15 This document is an early example of a decree. I would like to seize the opportunity to thank Naïm Vanthieghem for his comments and remarks on this document. For more about this genre of documents, see Vanthieghem's forthcoming article "Le décret: genése d'un genre documentaire au regard de nouveaux papyrus inédits."

16 This papyrus with some other fragments came from W.F. Petrie's excavations in the Fayyūm in the late 188os and now kept at the department of Greek and Latin at the University College London.

17 I am grateful to Nikolaos Gonis for providing me with the image and for allowing me to work on and publish this papyrus.
} 
lines have partially been preserved on the top and the bottom. At the top a margin of about eight centimeters has been left blank. The seal affixed at the foot of the document is impressed with unclear intaglio, presumably carrying the name of the executive, whose first name is missing at the top of the document. ${ }^{18}$ Diacritical dots are only visible on one character.

2.1 Text

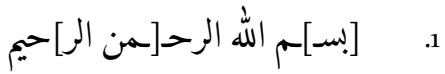

$$
\begin{aligned}
& \text { 2. }
\end{aligned}
$$

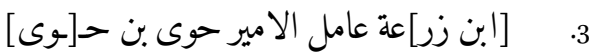

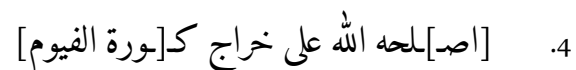

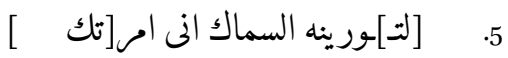

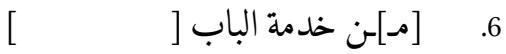

$$
\begin{aligned}
& \text { 7. [وم-[ن يلزهه ذلك من اهل الق[برى] }
\end{aligned}
$$

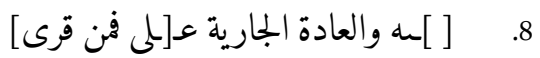

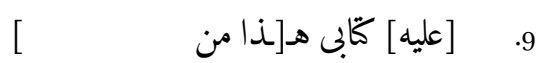

$$
\begin{aligned}
& \text { 10. }
\end{aligned}
$$

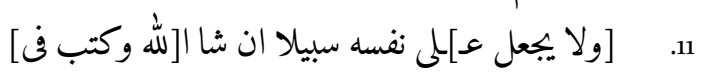

$$
\begin{aligned}
& \text { 12. [ربيع الا]خر سنة }
\end{aligned}
$$

\subsection{Diacritical Dots}

\subsection{Translation}

1. [In the $\mathrm{n}$ ] ame of God the Compassio[nate, the Mer]ciful.

2. [This is a le]tter [from ]

3. [son of Zur]'a, the executive ('âmil) of the amīr Huwayy ibn $\mathrm{Hu}$ [wayy, ]

18 For more about seals see Petra M. Sijpesteijn, "Seals and Papyri from Early Islamic Egypt," 
4. [may God [pre]serve him, over the finance (kharāj) of [the district of the Fayyūm]

5. [for Ta]wrinah the symmachos. I or[dered you ]

6. [fro]m serving the impost [ ]

7. [and who is] obligated (to pay) this from the people of the villa[ges]

8. [ ] ... (according to) the current schedule $\mathrm{o}$ [n. And whoever]

9. reads this letter of mine [from

10. [let him] know ... of [his affair]

11. [and let him not find] a way against himself, if [God] wills. [And it has been written in]

12. $\left[\right.$ Rabì $\left.^{`}\right]$ II of the year $[1] 82$.

\section{$2.4 \quad$ Commentary}

1. The $b \bar{a}^{\prime}$ and $\sin$ of bism are missing. Similarly, the mimm and nün of al-rahmān and the $r \bar{a}$ of al-rahim are lost in the lacuna. The upper traces of the alif and läm of al-rahim are still visible. The tail of the mim of al-rahim extends vertically and intersects with the $b \bar{a}$ of $k i t \bar{a} b$ in the next line.

2-5. hädhā kitāb min fulān ibn fulān 'ämil al-amìr fulān ibn fulān aṣlahahu Allāh 'alä kharāj kūrat kadhà li-fulān ibn fulān is the standard formula of this type of documents. Cf. CPR XXI 2.5-6, (c. 176/792); 5 (182/799); Werner Diem, "Einige frühe amtliche Urkunden aus der Sammlung Papyrus Erzherzog Rainer (Wien)," Le Muséon 97 (1984), 109-158, nos. 4.2-5 (c. 177-178/794-795); 5.1-2 (c. 159-161/775-777); 7.2-3 (168/784); 8.2 (116/734); CPR XVI 1.2-3 (206/821). The $b \bar{a}$ of kita $\bar{b}$ extends horizontally at the end of line two. See also the $b \bar{a}$ of $a l-b \bar{a} b$ in line 6.

3. Only the 'ayn and $h \bar{a}$ ' of Zur'a are still visible at the beginning of this line. The reading is tentative. As for Ibn Zur'a's superior, Huwayy b. Huwayy, he was Egypt's highest authority over the fiscal administration. Huwayy b. Huwayy issued also a number of official weights and measures which confirm this authority. For the attestations of Huwayy b. Huwayy on weights and measures, see Paul Balog, Umayyad, 'Abbäsìd and Tülünìd Glass Weights and Vessel Stamps (New York: American Numismatic Society, 1976), 211-212; 'Abd al-Raḥmān Fahmy, Șanj al-Sikka fì Fajr al-Islām (Cairo: Maṭba'at Dār al-Kutub al-Mișriyya, 1957), 151-154. ${ }^{19}$

in Seals and Sealing Practices in the Near East: Developments in Administration and Magic from Prehistory to the Islamic Period, eds. Ilona Regulski, Kim Duistermaat and Peter Verkinderen (Louvain: Peeters, 2012), 171-182.

19 See also George Miles, "Early Islamic Weights and Measures in Muntaza Palace, Alexandria," Journal of the American Research Center in Egypt 3 (1964): 111. 
4. There is not much space available at the beginning of this line to restore anything more than the blessing așlahahu Alläh. In the papyri from firstsecond/seventh-eighth centuries, the first mention of the caliph (amir almu'minin) or the governor (amir) is always followed by this blessing. It also occurs frequently on weights. The caliph Yazìd II (r. 101-105/720-724) is said to have started this practice in 101/720. The last Umayyad financial director of Egypt, 'Abd al-Malik b. Marwān (in office 132/750), was the first official of this rank to be given this blessing in documents and it remained in use for Abbasid governors until 176/792 after which it is no longer attested. See Sijpesteijn, Shaping a Muslim State, 1.4 (second/eighth century) and commentary; FrantzMurphy, Arabic Agricultural Leases, 119. Other blessings are also given to amirs in documents, such as, hafizahu Alläh, cf. P.World, pp. 132-134 (ca. 176-177/795); CPR XXI 4 (ca. 179-180/796) and ațāla Allāh baqüa ahu, cf. Diem, "Einige frühe amtliche Urkunden," nos. 6.4 (180/796) and 7.3 (168/784). See also Khan, Arabic Papyri, 138-140. Of küra only the kăf and traces of the wāw are still preserved. Al-Fayyūm is reconstructed on the basis of the place of discovery.

5. Al-sammāk (pl. samāmika) is the Arabic transcription of the Greek symmachos ( $\sigma \dot{v} \mu \alpha \alpha \chi \varsigma$ ), referring to an official involved in the collection of taxes. The title appears in Greek, Coptic and Arabic papyri (Sijpesteijn, Shaping a Muslim State, 14.5 (second/eighth century) and commentary). Tawrinah is the Arabic form of the Greek and Coptic name Taurinos or Taurine. Cf. P.Heid.Arab. I app. F.

6. The nün of min is still visible at the beginning of this line. A little stroke is attached at the top of the dāl of khidma. Bāb (pl. abwāb) is a technical fiscal term, referring to different categories of taxes (Jāsir Abū Șafiyya, Bardiyyāt Qurra b. Sharīk al-'Absī (Riyadh: Markaz al-Malik Fayṣal li-l-Buhūth wa-l-Dirāsāt al-Islamiyya, 2004), 94-96). The term also appears in the form of $a b w \bar{a} b$ al-mäl meaning different categories of money tax (Nabia Abbott, The Kurrah Papyrifrom Aphrodito in the Oriental Institute. Studies in Ancient Oriental Civilisation 15 (Chicago: Chicago University Press, 1938), 4.14-15, 5.3-4, 19-21; Adolf Grohmann, Arabic Papyri in the Egyptian Library, vol. 3 (Cairo: Egyptian Library Press, 1938), 146.2; 158.8 and the commentary, all dated $91 / 710$ and provenance is Aphroditō/Kawm Ishqūh).

7. wa-ma $]$ n yulzimuhum dhälika min ahl al-qu[rā]. The $y \bar{a}$ of al-qurā can be seen extending backwards at the end of this line. In the Islamic period qarya (Gr. $\chi \omega$ piov) had the technical sense of a fiscal unit, consisting of a settlement and the accompanying land (Sijpesteijn, Shaping a Muslim State, 2.8 (second/eighth century) and commentary). The expression ahl al-qurā often appears in administrative letters. Cf. fa-innahu balaghanīanna ba'd ahl al-qurā, P.MuslimState 10.4; ahl al-qurā fì, wa-wakkil bi-qabdihi afḍl ahl al-qurā wa- 
ashaddahum, P.MuslimState $23.7,16$, all dated to the second/8nd century and coming from the Fayyūm.

8. At the beginning of this line a denticle and a $h \bar{a}$ or a $t \bar{a}$ marbüta can be detected. The idiom al-âda al-järiya is unattested in the papyri, but the meaning can be inferred from later expressions such as, al-rasm al-järi (FrantzMurphy, Arabic Agricultural Leases, 113). Of 'alä only the 'ayn can be seen at the end of this line.

9-11. The expression fa-man quria ['alayhi] kitäbì hä[dhā min] [wa-l-ya]'lam ... min amrihi [wa-lā yaj'al] 'alä nafsihi sabïlan in shäa $[$ [Allāh] is restored on the basis of parallels. Cf. P.Ryl.Arab. I 17.7-9 (second-third/eighth-ninth centuries); P.Cair.Arab. III 171.5 (242-247/856-861, probably from al-Ushmūnayn); Carl H. Becker, "Arabische Papyri des Aphroditofundes," Zeitschrift der Assyriologie und verwandte Gebiete 20 (1907): 68-104, no. 4.12, 91/710, provenance is Aphroditō/Kawm Ishqūh.

10. The second word in this line is illegible. Only the final läm-alif is clear to me. Of wa-l-yalam only the 'ayn, läm and mim are preserved at the beginning of this line. Similarly, the $r \vec{a}$ and $h \bar{a}$ ' of amrihi are missing at the end.

11. The orthography is written for على which is frequent in the early papyri (Hopkins, Grammar of Early Arabic, §55). For the expression wa-kutiba and other expressions to be used to signal the closure of letters, see Khan, Arabic Papyri, 194 .

12. At the beginning of this line the $k h \bar{a}$ and $r \bar{a}$ ' of al- $\bar{a} k h i r$ of Rabī' II can be detected. The date is given in Greek numerals. ${ }^{20}$ Of the date only the two signs $\pi \beta$ or 82 are preserved, which surely indicates the year of $182([\rho] \pi \beta)$.

\subsection{Huwayy b. Huwayy (in Office third of Ramaḍān 181-Ramadān 182/28th October 797-November 798 )}

The amir mentioned in these two documents, Huwayy b. Huwayy, is one of those governors unlisted and forgotten by medieval historians. Moreover, his name is always mispresented by them, by copyists and even by modern scholars. Fortunately, the present documents and a number of weights affirm that Huwayy b. Huwayy was designated as amir and that he was appointed at the head of the religious management of the Muslim community and the financial administration of the province, i.e. 'alā al-șalāh wa-l-kharāj. Al-Kindī identifies him in two accounts in a general way as one of the notables (ashräf) of Egypt. ${ }^{21}$ Ibn Yūnus (d. 347/958) in his biographical dictionary mentions in a very laconic

$20 \quad$ Grohmann, Egyptian Library, 1:81.

21 al-Kindī, al-Wulāt, 389, 398-399. 
style that Huwayy came to Egypt as governor "qadima Mișr wāliyan" without specifying his function. ${ }^{22}$ Khalīfa b. Khayyāt (d. 240/854) misspelled his name as Huwayy b. Juwayn, but he counted him among the governors of Egypt during the reign of Hārūn al-Rāshīd (r. 170-193/786-809), namely as the successor of 'Ubayd Allāh b. al-Mahdī (in office Muharram-Ramaḍān 179/March-November 795 and Jumādā II 18o-Ramaḍān 181/August 798-October 797). Nevertheless, he did not mention whether he ruled Egypt after the first or the second term of 'Ubayd Allāh b. al-Mahdī. ${ }^{23}$ Centuries later, Ibn Duqmāq (d. 8og/1406) misspelled his name as Khuwayy b. Huwayy, when he mentioned a guardhouse named after him in Fustâtat. ${ }^{24}$ Fortunately, this guardhouse is precisely recorded in a deed of a lease of a shop on parchment dated 280/893. The editor of this document quotes Ibn Duqmāq and edits the name as Khuwayy b. Huwayy. ${ }^{25} \mathrm{On}$ the photograph of the document, however, no dot can be detected above the $h \bar{a}$. Strangely enough, Ibn Duqmāq also records a funduq named after Huwayy b. Huwayy giving the name correctly. ${ }^{26}$ Years later, al-Maqrīzī (d. 845/1442) mentions that Huwayy was nominated as financial director of Egypt after 'Ubayd Allāh b. al-Mahdī in the year 181/797. ${ }^{27}$ Al-Maqrīzī also mentions that Huwayy's sons took over high positions in Egypt, a point to which I shall return.

Documentary sources including papyri and weights give us more accurate information regarding this official. Four coin weights affirm that Huwayy b. Huwayy was designated as amir. ${ }^{28} \mathrm{But}$ it is not clear whether the title refers to the financial director or to the governor appointed over șalāh only, since both of them were given the title of amir. ${ }^{29}$ Now let us turn from weights to papyri, which allow us to identify this official and his position further. Document 1 affirms unambiguously that Huwayy b. Huwayy was appointed at the head of the administrative and financial hierarchy (al-șaläh wa-l-kharāj) and

22 Abū Sa'ìd 'Abd al-Rahmmān b. Aḥmad ibn Yūnus, Tārīkh Ibn Yūnus al-Miṣrī, ed. 'Abd alFattāḥ 'Abd al-Fattāḥ (Beirut: Dār al-Kutub al-'Ilmiyya, 200o), 2:71.

23 Abū 'Amr Khalīfa b. Khayyāṭ ibn Khayyāt, Tārīkh Khalīfa b. Khayyāt, ed. Mușțafa N. Fawāz and Ḥikmat K. Fawāz (Beirut: Dār al-Kutub al-'Tlmiyya, 1995), 307.

24 Ibrāhīm b. Muhammad ibn Duqmāq, al-Intișār li-wāsațat 'aqd al-amașār (Beirut: al-Maktab al-Tujārī li-l-Tiiba‘a wa-l-Tawzī‘ wa-l-Nashr, n.d.), 14.

25 Khan, Arabic Papyri, 13.3 and the commentary.

26 Ibn Duqmāq, al-Intișār, 40.

27 Taqiyy al-Dīn Aḥmad b. 'Alī al-Maqrīzī, al-Muqaffā al-Kabìr, ed. Muhammad al-Yalāwī (Beirut: Dār al-Gharb al-Islāmī, 1991), 2:708.

28 See above the commentary to document 2, line 3.

29 For this discussion, see Adolf Grohmann, Protokolle [1:] Einleitung und Texte. Mit einer Schrifttafel und vier Abbildungen im Texte. [2:] Tafeln, Corpus Papyrorum Raineri 3.1/2-3 (Wien: Burgverlag Ferdinand Zöllner, 1923-1924), 120; Sijpesteijn, Shaping a Muslim State, $73^{-81 .}$ 
that he appointed a certain Ibn Falīh in charge of all dīwāns (al-zimām) and the fiscal administration (al-kharāj) and a certain Abū 'Ubayda b. 'Uqba b. Nāfi' over Upper Egypt and the fiscal administration (al-Sa ìd wa-l-kharäj). Narrative sources indicate that Egypt's administration was divided into two main districts after the conquest, one for Upper Egypt or al-Şaid and another one for Lower Egypt or Asfal al-Ard. At the head of each district stood an official, who was selected and appointed by the governor himself. ${ }^{30}$ Papyrological evidence confirms this situation, indicating that the whole financial organization was divided in two, with separate dīwanns being established and a double set of clerks and officials appointed. ${ }^{31}$ This information solves the apparent paradox of repeating the office of fiscal supervisor in al-zimām wa-l-kharäj and in alSaìd wa-l-kharāj. Kharāj here does not refer to the kharäj of the entire province but to the fiscal office associated with each region; e.g. al-Sa $a^{i} d$ wa-l-kharāj means Upper Egypt and its taxes. As for al-zimām (pl. azimma) it is an office of control and auditing. The Abbasid caliph al-Mahdì (r. $15^{-169 / 775-785)}$ is said to have founded this office in $162 / 778-779$, when the task of overseeing and controlling all the dīwans of the administration became too much for a single person. It is suggested that every dīwān came to have a zimām attached to it by way of control and that responsibility of all the azimma might be held by one man, who had the general function of control over all the diw āns. ${ }^{32}$ This latter office is definitely the one that Ibn Falih was holding. As for the finance office included in the title al-zimām wa-l-kharāj, this could refer to the finances of Lower Egypt corresponding to the one of Upper Egypt which was held by Abū 'Ubayda. In any case, Ibn Falị̄ was a subordinate to Ḥuwayy and answered directly to him as did Abū 'Ubayda.

Ibn Falih in our papyrus is probably the same person mentioned by Ibn Yūnus and Ibn Duqmāq under the name Muḥammad b. Sulaymān b. Falīḥ, whose house in Fusțāt is well known in khiṭat works as Dār ibn Falīh. ${ }^{33}$ It is remarkable that Ibn Falih got his house built in 181/797, the exact year he headed the treasury according to the papyrus edited above. As for Abu 'Ubayda b. 'Uqba b. Nāfi', Margoliouth identifies him as the son of the famous governor of Ifrīqiya 'Uqba b. Nāfi' al-Fihrī (in office 49-55/669-674 and 62/681). On the basis of this identification Grohmann dated the papyrus to the second half of the first century. ${ }^{34}$ Margoliouth's identification appears to be wrong. Abū

3 al-Kindī, al-Wulāt, 35, 106, 182, 192, 278.

31 Grohmann, Egyptian Library, 3:143; Grohmann, Historischen Geographie, 24.

32 A.A. Duri et al., "Dīwān," in Encyclopaedia of Islam, 2nd ed. (Leiden: Brill), 11:509.

33 Ibn 'Abd al-Hakam, Futūh Miṣr, 119; Ibn Duqmāq, al-Intișār, 9; Ibn Yūnus, Tārīkh, 2:2o6.

34 Grohmann, From the World, 173. 
'Ubayda b. 'Uqba b. Nāfi' is the son of 'Uqba b. Nāfi' al-Ma'āfirī (d. 197/812). Note that there is a gap of more than one hundred and thirty years between the former and the latter. Ibn Yūnus records 'Uqba b. Nāfi' al-Ma'āfirī in his dictionary as a theologian, who died in Alexandria in 197/812. He added that 'Uqba's offspring, residing in Fusțāt, was highly honoured and ranked. Abū 'Ubayda was definitely one of them..$^{35}$

In sum, document 2 confirms only that Huwayy b. Huwayy held authority over the fiscal administration. Document 1 gives conclusive evidence that Huwayy b. Huwayy was not merely a member of the elite of Fusțăt or a financial director, as recorded by some chroniclers and document 2, but indeed a governor who was holding both the office of religious leadership and of financial directorship as some other narrative sources indicate.

While the nature of Huwayy's office might hereby be clarified, the length of it is still uncertain. The two documents edited above can help define his specific dates of appointment and dismissal. As shown above, the historian Khalīfa b. Khayyāt enumerates Huwayy b. Ḥuwayy after 'Ubayd Allāh b. alMahdī and this fact is corroborated by al-Maqrīzī, who affirms that Huwayy succeeded 'Ubayd Allāh b. al-Mahdī precisely in the year 181/797, albeit according to him as financial director only. 'Ubayd Allāh b. al-Mahdī was dismissed on the third of Ramadian of the year 181/797 which fits perfectly with the date of Huwayy's appointment stated in Document 1, lines 20-21. Document 2 affirms that Huwayy was in office in Rabī II of the year $182 / 798$ and presumably continued to be so until the appointment of al-Layth b. al-Faḍl (in office Shawwāl 182-Jumādā II 187/798-803), as recorded in Khalīfa b. Khayyāț's list.

Finally, a short biography for Huwayy b. Huwayy and his family can now be formulated on the basis of the scattered accounts in chronicles and documentary sources. Huwayy b. Huwayy apparently came from Iraq to Egypt as governor on Sunday the third of Ramadān of the year 181/797. He stayed in office for a short period, presumably one year. When he was dismissed, Huwayy stayed in Egypt and remained a member of the élite of Fusțāt (ashräf mișr), but he held no more official position. ${ }^{36}$ During his time in Egypt, Huwayy was involved in various struggles with the judges and jurists of Egypt. First with the judge Muhammad b. Masrūq (in office 177-184/793-80o) who introduced very strict regulations concerning the appointment of witnesses in court determining that only a restricted number of persons could act as official witnesses. This decision was rejected by the élites including Huwayy b. Huwayy and as a conse-

35 Ibn Yūnus, Tārīkh, 1:349.

36 al-Kindī, al-Wulāt, 389 . 
quence Muhammad $b$. Masrūq showed great harshness towards them all. ${ }^{37}$ The second incident was with the judge al-'Umarī (in office 185-194/801-809), who refused Huwayy's testimony regarding the parentage of the people of al-Haras to Hawtak, a clan of Qudāa a, ${ }^{38}$ due to a previous strife between Huwayy and Ashhab b. 'Abd al-'Azīz (d. 204/820). ${ }^{39}$ In the year 200/816 Huwayy passed away leaving behind five sons. These all held high positions mainly in the police and army. ${ }^{40}$ Ahmad b. Huwayy probably the eldest son of Huwayy was appointed at the head of the police, i.e. șăhib al-shurța, by the governor 'Abd Allāh b. Muhammad al-'Abbāsì (in office 189-19o/8o5-8o6). The latter later dismissed him for no apparent reason. ${ }^{41}$ Ten years later Ahmad held the same position under the second term of the governor al-Muțtialib b. 'Abd Allāh (in office 199$200 / 814-815){ }^{42}$ In the year 196/811, Ibrāhīm b. Huwayy was appointed over the cities of Banā, Sanhūr and Sandafā ${ }^{43}$ during the fight between 'Abbād b. Muhammad b. Hayyān, deputy of the caliph al-Ma'mūn (r. 198-218/813-833), and Rabīa b. Qays, deputy of the caliph al-Amīn (r. 193-198/8o9-813). ${ }^{44}$ Ibrāhīm was killed during this fight in a battle against a certain Yazīd b. al-Khațāāb in Damraw.45 Abū al-Karam b. Huwayy was killed in Fusțāț, because he was the governor's deputy over it in $197 / 812 .{ }^{46}$ Their fourth brother Muhammad was also killed in Fusțăt in the month of Muharram of the year 198/813. ${ }^{47}$ Ṣalih was probably the youngest of Huwayy's sons, owing to the report that he was born and brought up in Egypt..$^{48}$ Ṣalih died in $245 / 859 \cdot{ }^{49}$ It may also be worth men-

37 al-Kindī, 389 .

38 Abū al-Munzir Hishām b. Muhammad b. al-Kalbī, Nasb Máad wa-l-Yaman al-Kabīr, ed. Nājī Ḥasan (Beirut: Maktabat al-Nahḍa al-'Arabiyya, 1988), 714.

39 al-Kindī, al-Wulāt, 398.

40 al-Maqrīzì, al-Muqaffā, 3:708.

41 al-Kindī, al-Wulāt, 142.

42 al-Kindī, 142, 154.

43 For Banā, Sanhūr and Sandafā, see Muhammad Ramzī, al-Qāmūs al-jughrāfì li-l-bilād almișrīya min 'ahd qudamā' al-mișrīȳin ilā sanat 1945 (Cairo: al-Hay'a al-Mișriyya al-'̄̄mma li-l-Kitāb, 1994), part 2, 2:70-71, part 1, 287, part 1, 285; Sharaf al-Dīn Yahyā b. al-Maqarr b. al-Jī̄an, al-Tuhfa al-san̄ya bi-asmä’ al-bilād al-mișrīya, ed. Bernhard Moritz (Cairo: AlMațbaca al-Ahliyya, 1898), 73, 81; Shihāb al-Dīn Yāqūt b. Abd Allāh Yāqūt al-Ḥamawī, Mújam al-buldān (Beirut: Dār Șādir, 1977), 1:495, 3:268; As'd b. Mammātī b. Mammātī, Kìtāb qawānīn al-dawāwīn, ed. 'Azīz S. 'Ațiya (Cairo: Maktabat Madbūlī, 1991), 214, 144, 148.

al-Kindī, al-Wulāt, 149-150.

46 al-Kindī, al-Wulāt, 151.

47 al-Kindī, 151.

48 Ibn Yūnus, Tārīkh, 1:240.

49 Ibn Yūnus, 240. 
tioning that Ṣālị̣ b. Ḥuwayy and his grandson Isḥāq b. Ibrāhīm (d. 320/932) were famous hadith transmitters in Egypt. ${ }^{50}$

\section{Letter Mentioning the amīr Muhammad b. Sa ${ }^{c} \overline{1} d$}

Provenance unknown

$16 \times 13 \mathrm{~cm}$

P.CTYBR. inv. 2733

$15^{2-157 / 769-773}$

Pl. 3

Dark brown papyrus written in black ink with a medium-thick pen accross the fibers. The papyrus is badly damaged and the top is missing resulting in a loss of at least three lines. The original cutting lines have partially been preserved on the other three sides. There are several lacunae in different places of the papyrus which have caused damage to the text. The ink has also faded in places obscuring the reading. The text is laid out in paragraphs. The verso is blank. An address may have been written at the top of the verso but is now lost. A few diacritical dots are visible.

3.1 Text

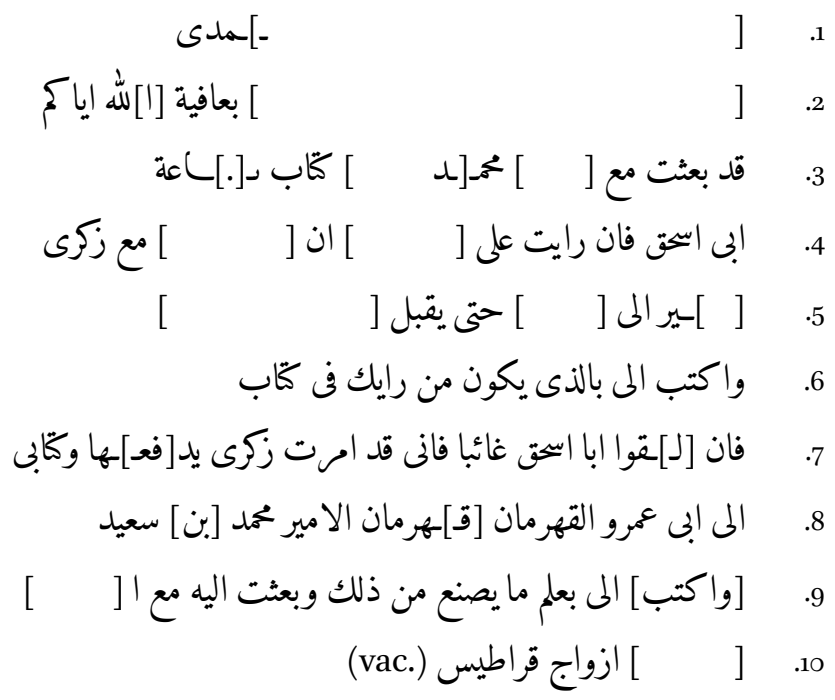

$5^{\circ} \quad$ al-Ḥāiz b. Mākūla b. Mākūla, al-Ikmāl fi r raf' al-irtiyāa 'an al-mu’talaf wa-l-mukhtalaf fì al-asmā' wa-l-kunā wa-l-ansāb, ed. 'Abd al-Raḥmān Y. al-Ma'amī (Cairo: Dār al-Kitāb alIslāmī, 1993), 2:574-575. 


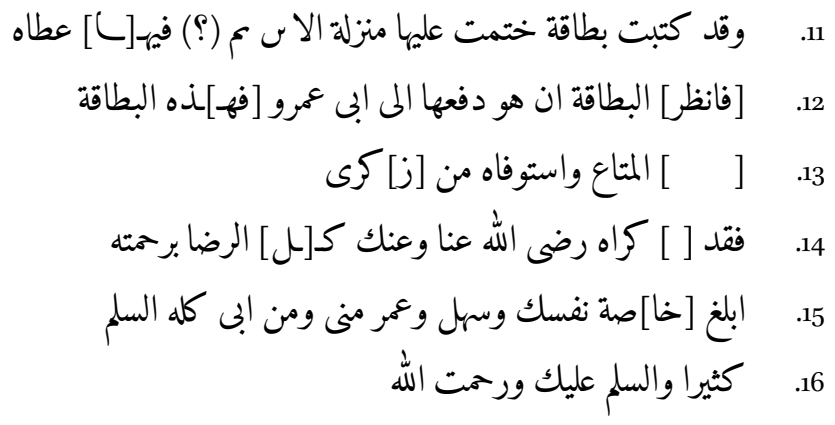

3.2 Diacritical Dots

$$
\text { 6) الذي؛ يكون؛ من } 7 \text { ) غاسا؛ كابي 8) سعيد 9) نصنع 10) وراطيس 11) عليها؛ الابـ 12) عنك }
$$

\subsection{Translation}

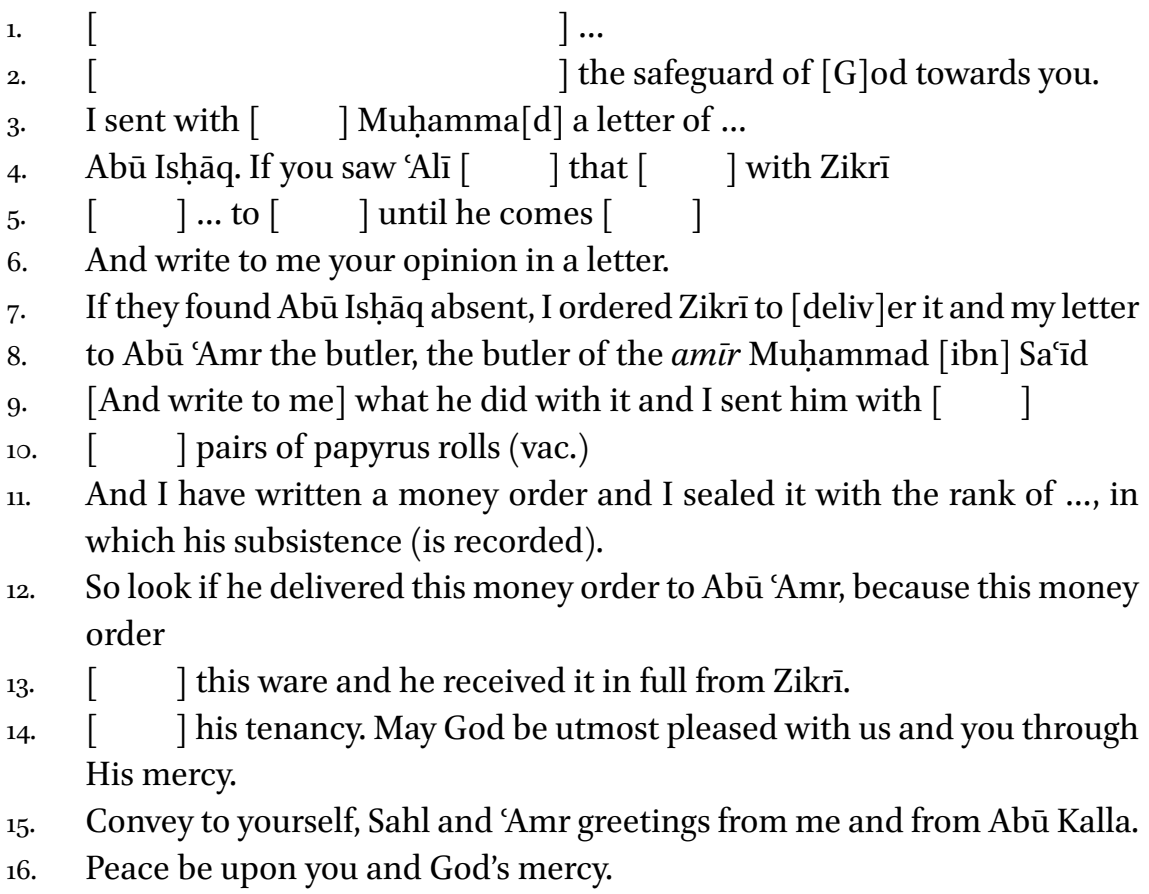




\subsection{Commentary}

1-2. The beginning of this letter with the basmala and the introductory formula is missing. The remains of the second line, however, seem to be part of this opening section and the contents of the letter suggest that not more than three lines are lost at the top. Bi-äafyat $[A l] l a \bar{a} h$ iyyākum. This expression and variants of it often follow the announcement of receiving the addressee's letter and becoming informed of the sender's well-being. Cf. balaghani kitäbuka fa-qara'tuhu wa-fahimtu mā dhakarta fìhi min 'äfiyat Allāh ìyākum fa-'un 'imat bi-dhālika surūrunā, Jean David-Weill, "Papyrus Arabes du Louvre II," Journal of the Economic and Social History of the Orient, 14 (1971): 1-24, 11.6-7 (second/eighth century). The plural form used in iyyākum contrasts with the singular used in the rest of the letter.

3. Only traces of letters and words can be read in this line due to the fragmentary state of the top of the papyrus.

4. Abì Ishāa fa-in ra'ayta 'Alī. The conditional using in is expected to be followed by $f a$-in the apodosis if it is a verbal sentence, expressing a desire, command or prohibition. Isḥāq is written with a scriptio defectiva of medial $\bar{a}$ as it is written in line 7 (Hopkins, Grammar of Early Arabic, § 1o.b.i). For this name, see, Shams al-Dīn Abū 'Abd Allāh Muḥammad b. Aḥmad al-Dhahabī, al-Mushtabih fial-rijäl, edited by P. De Jong (Leiden: Brill, 1893), 241. For its attestations in the papyri, see Younes, Joy and Sorrow, 134.

5. Only a few letters can be read among the ink traces remaining on this line.

6. wa-ktub ilayya bi-lladhì yakūnu min ràyika fì kitāb. This expression and variants of it occur frequently in letters to request the addressee's opinion. See for example, fa-a'limnī ra'yaka fìhā, Petra M. Sijpesteijn, "The Archival Mind in Early Islamic Egypt," in From al-Andalus to Khurasan: Documents from the Medieval Muslim World, eds. Petra M. Sijpesteijn, et al. (Leiden: Brill, 2007), 163186, no. 1.5 (second/eighth century); fa-ktub mā ra'yuka wa-anā 'alā bay'ihā, P.Marchands III 44.6 (third/ninth century); a limnī ra'yaka abqāka allāh, Yusūf Ragib, "Lettres Arabes II," Annales Islamologiques 16 (1980): 1-29, no. 16.5 (third/ ninth century); fa-'arrifnì ra'yaka li-aqifa 'alayhi in shäa Allāh, P.Khalili I 18.8 (third/ninth century). The two words ilayya and bi-lladhi are widely set apart.

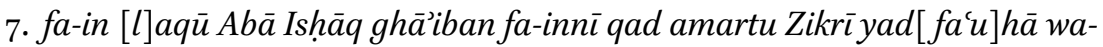
kitāabi. The personal pronoun in yadfa'uhä refers perhaps to the bițāqa mentioned in lines 11 and 12. The word yadfa uhä can also be read as bi-daf'ihā. For the use of the particle qad in the papyri, see Eva M. Grob, Documentary Arabic Private and Business Letters on Papyrus: Form and Function, Content and Context (Berlin/New York: De Gruyter, 2010), 138-139.

8. ilā Ab̄̄ Amr al-qahramān qahra [m] ān al-amìr Muhammad ibn Sa'ìd. Ilā is written with a long space between the alif and the lām while the $y \vec{a}$ 'returns to 
the right to cover the space as in line 6. Al-qahramān is a Persian title meaning the butler of the governor or the king. ${ }^{.1}$ To the best of my knowledge, this is the first attestation of this title in papyri. For the occurrence of Muhammad b. Saīd on weights, stamps and papyri, see Grohmann, Protokolle, 120; Adolf Grohmann, "Arabische Papyri aus den Staatlichen Museen zu Berlin," Der Islam 22 (1934): 14.

9. Due to the crumbling of the fibers at the beginning and the end of this line, no continuous sense can be made of it.

10. For qarāțīs (sing. qirțās), papyrus rolls, see Grohmann, From the World, 22-30; Adolf Grohmann, Einführung und Chrestomathie zur arabischen Papyruskunde, vol. 1, Einführung (Prague: Státní Pedagogické Nakladatelství, 1954), 68-71. A number preceeding azwāj qarătīis is to be expected in the lacuna at the beginning of this line (Hopkins, Grammar of Early Arabic, § 84.g). A space has been left blank at the end of this line indicating the beginning of a new paragraph in the next line.

11-12. Al-bitāaqa or the money order is the subject of numerous papyri. These money orders were quite small, written on documents of very small size. Cf. Grohmann, From the World, 147. I was not able to find a satisfactory reading for the word after manzila in line 11. Atä $\vec{u}$ hu is written without hamza (Hopkins, Grammar of Early Arabic, § 21). For the term 'ața’', see Petra M. Sijpesteijn, "Army Economics: An Early Papyrus Letter Related to 'Ațā' Payments," in Studies in the Social and Economic History of the Medieval Middle East: Essays in Honour of Avram L. Udovitch, edited by. R. Margarati, A. Sabra, and P.M. Sijpesteijn (Leiden: Brill, 2011), 245-267.

13. Form $x$ of the root $w-f-y$ refers in legal documents and texts to the complete payment of a debt. Cf. CPR XXIV 7.10-11 (333/945), 8.7 (345/956), 19.14 (third/ninth century).

15. For the expression abligh khāșsat nafsika al-salām, see Grob, Arabic Private, 72-74; Younes, Joy and Sorrow, 214-215.

16. wa-l-salām 'alayka wa-rahmat Allāh. Al-saläm is written with a scriptio defectiva of the long $\bar{a}$ (Hopkins, Grammar of Early Arabic, §10.a) and rahmat is written with a $t \vec{a}$ tawilla instead of a $t \vec{a}$ marbüța in the status constructus (Hopkins, Grammar of Early Arabic, § 47.a).

$51 \quad$ J.T.P. de Bruijn, “Kahramān," in Encyclopaedia of Islam, 2nd ed. (Leiden: Brill, 1978), 4:444445; Muḥammad b. Mukarram b. Manẓūr, Lisān al-'arab, ed. 'Abd Allāh 'A. al-Kabīr et al. (Cairo: Dār al-Ma'ārif, n.d.), 2:3764. 


\subsection{Muhammad b. Sa ìd (in Office 152-157/769-773)}

According to al-Kindī, Ibn Yūnus, al-Jahshiyārī and al-Maqrīzī, Muḥammad b. Saîd administrated the finances of Egypt for an uncertain period sometime between 142 and 157 (759-774). 52 Al-Ṭabarī, Ibn al-Athīr (d. 630/1234) and Ibn Kathīr (d. 774/1373) record him as the successor of the governor Yazīd b. Hătim (in office $\left.144-15^{2} / 761-769\right)$ and delineate his term of activity for five years (152157/769-773) ${ }^{53}$ It is, however, striking that even very reliable Egyptian historians, such as al-Kindī and al-Maqrīzī, affirm that 'Abd Allāh b. 'Abd al-Raḥmān b. Mu'āwiya was the direct successor of Yazīd b. Hātim. In his list of governors of Egypt, Von Zambaur noticed this discrepancy and suggested that 'Abd Allāh b. 'Abd al-Rahmmān b. Mu'āwiya was only a commander under the authority of Muhammad b. Sa'id. ${ }^{54}$ In his attempt to solve the paradox of the names of the governors of Egypt given by al-Tabarī and al-Kindī for the years 152-162/769778, Hugh Kennedy reached the following conclusion: "al-Tabarī was working from records which detailed those in charge of the financial administration, while the local tradition used by al-Kindī emphasizes the role of the wäli who supervised prayers and public order."55 However, the opposite seems to be the case with Muhammad b. Sa'īd. Al-Kindī identifies Muḥammad b. Saīid as financial director, while al-Ṭabarī lists him among the governors. Al-Kindī refers to Muhammad b. Saîd in three accounts. In two of them Muhammad b. Sa'id cannot be anything but the financial director of Egypt while the third account is a bit confusing. In what follows I would like to shed light on these accounts aiming to reconstruct a better understanding of Muhammad b. Sa îd's responsibilities.

In the first account the chief of police, Muhammad b. Mu'āwiya, under the governor Muhammad b. al-Ash'ath (in office 141-143/758-76o) insulted the previous governor Abū 'Awn 'Abd al-Malik b. Yazīd (in office 133-136/750-753 and 137-141/754-758) in the middle of the Mosque of 'Amr b. al-'̄ș. He did so out of revenge because Abū 'Awn had had Muhammad b. Mu'āwiya beaten and reduced his subsistence from 200 to 120 dinars. The whole story occurred in

52 al-Kindī, al-Wulāt, 361-362; Ibn Yūnus, Tärīkh, 2:2o6; Abū 'Abd Allāh Muḥammad b. 'Abdūs al-Jahshiyārī, Kitāb al-wūzarā' wa-l-kuttāb, ed. 'Abd Allāh al-Ṣāwī (Baghdad: al-Maktaba al'Arabiya, 1938), 102; al-Maqrīzī, al-Muqaffā, 5:674.

53 Muhammad b. Jarīr al-Ṭabarī, Tārīkh al-rusul wa-l-mulūk, ed. Muhammad Ibrāhīm (Cairo: Dār al-Ma'ārif, 1969), 8:41; 'Alī b. Muhammad b. al-Athīr, al-Kāmilfíal-tārīkh, ed. 'Abd Allāh al-Qāḍī (Beirut: Dār al-kutub al-'Ilmiyya, 1987), 5:202; Ismā̄̄il b. 'Umar b. Kathīr, al-Bidāya wa-l-nihāya, ed. 'Abd Allāh al-Turkī (Cairo: Dār Hajr, 1997), 13:425.

54 Eduard von Zambaur, Manuel de Généalogie et de Chronologie pour l'Histoire de l'Islam (Hannover: Orientbuchhandlung Heinz Lafaire, 1955), 25-28.

55 Kennedy, "Central Government," 33, n. 46. 
the presence of Muhammad b. Sa'îd, the "financial director" (șähib al-kharāj). ${ }^{56}$ In the second account Muhammad b. Saîd is also identified as the financial director of Egypt ('alā kharāj mișr). The account starts when Muhammad b. Sa īid appointed a certain Ibn 'Utba over Itrīb. ${ }^{57}$ Ibn 'Utba, however, behaved so aggressively and coarsely to the people of Itrīb that a certain Ibn Shajara al-Murādī, a soldier in the army of 'Abd Allāh b. Hudayj, decided to get rid of him. One evening Ibn Shajara was waiting with drawn sword for Ibn 'Utba to return from the office to his house. When he arrived, after sunset, Ibn Shajara attacked him. Ibn 'Utba fell down and his helmet rolled to the side. Mistaking the rolling helmet for a severed head Ibn Shajara thought he had succeeded in cutting Ibn 'Utba's head off. Ibn Shajara hastely returned to the army quarters. A little while later Ibn 'Utba was found unharmed. Muhammad b. Saîd ordered to imprison all the people of Itrīb. The famous scholar al-Layth b. Sa'd was also imprisoned but he received special treatment, presumably because of his status, and was released after one hour only. A report was sent to the caliph al-Manșūr (r. 136-158/754-775) who ordered the chief judge of Egypt, Abū Khuzayma (in office 144-154/761-771), to remain in Muhammad b. Saīd's office waiting for the caliph's instructions. The caliph's letter arrived before the end of the week. Muhammad kept it and waited for the judge to arrive in the afternoon. Once the judge entered the office Muhammad b. Sa'id gave him the letter and asked him to open it. The judge, however, refused insisting instead on opening it in court. When he went to the court he read the letter and ordered to free the prisoners and to kill Ibn 'Utba. Apparently still desiring to punish the people of Itrīb and in defiance of the caliph's interpretation, Muhammad b. Sa'ìd later on asked his retinue to suggest to him a strong man to be appointed over Itrīb in revenge for what its people did to Ibn 'Utba. ${ }^{58}$

In the third account Muhammad b. Saīd appears more as a governor than as a financial director. The account records the census of the tribe of Qays after their arrival in Egypt. ${ }^{59}$ We read: "we counted them (the people of Qays) under the rule ( fi wilayyat) of Muhammad b. Sa'id and we found them all, young and old and all those who are grouped in their household, five thousand, give or take two hundred." 60

\footnotetext{
56 al-Kindī, al-Wulāt, 109-110.

57 For Itrīb, see Ramzī, al-Qāmūs al-jughräfĭ, part 2, 1:18.

$5^{8}$ al-Kindī, al-Wulāt, 365-366.

59 In 109/727, the Muslim authorities in Egypt, reinforced by the caliph's support in Damascus, had decided to evacuate several hundred families belonging to the Arab tribe of Qays from Syria and settled them in rural areas in the eastern edge of the Delta for political and economic purposes. See al-Kindī, al-Wulāt, 76 .

60

al-Kindī, 77 .
} 
In sum, the three accounts show Muhammad b. Sa'ìd as a powerful independent-minded governor dealing with administrative matters such as maintaining law and order and appointing officials throughout Egypt and dealing with financial matters. This in turn leads us to conclude that Muhammad b. Sa īid was not only a financial director as was noted by al-Kindī, Ibn Yūnus, and al-Maqrīī later on, but also the governor of the province as was recorded by alṬabarī, Ibn al-Athīr and Ibn Kathīr. This assumption can be strengthened by the large number of weights, stamps, a papyrus protocol dated 153/770 (P.Berl.Arab. $13003)^{61}$ and document 3 .

From the various arguments set out above it can be concluded that Muhammad b. Saīid was holding both offices, al-ṣalāh wa-l-kharāj, in the years $15^{2-}$ 157/769-773 and that 'Abd Allāh b. 'Abd al-Raḥmān b. Mu'āwiya (in office 152155/769-772), his brother Muhammad (in office 155/772) and Mūsā b. 'Ulayy (in office $155^{\left.-161 / 72^{-}-778\right)}$ were only commanders under his authority and continued to be so under his successors. In the year 157/773 Muhammad b. Saîd was dismissed from office and on Sunday the tenth of Jumādā II 158/775 he passed away. ${ }^{62}$

\section{$4 \quad$ Conclusion}

The papyri edited in this paper are not alone in providing evidence for governors lacking in our narrative sources. The papyrus A.P. oo672 [= PERF 621] is a contract of lease issued by the financial official of the Fayyum in the name of another unlisted governor 'Umar b. Mihrān (in office 27 Safar-24 Rabī' I 176/June-30 July 792) who held the governorship for a short term. He went unnoted among the officeholders of Egypt by the historians except for an anecdote mentioned by al-Jahshiyārī quoting a record by 'Umar b. Mihrān himself.63 Another precious official document (A.P. $1176[=P E R F$ 610]) and a papyrus protocol (P.Berol. 12815$)^{64}$ record the name of the governor Abū Damra Muhammad b. Sulaymān (in office 159-161/775-778) who does not appear in al-Kindī's list either. ${ }^{65}$

\footnotetext{
61 Grohmann, "Staatlichen Museen," 13-14, no. 3.

62 al-Maqrīzī, al-Muqaffā, 5:674; Ibn Yūnus, Tārīkh, 2:206.

63 al-Jahshiyārī, al-Wūzarā', 171-174. See also Adolf Grohmann, "Aperçu de Papyrologie Arabe," Études de papyrologie 1 (1932): 23-95, 50; Frantz-Murphy, Arabic Agricultural Leases, 168-172; Grohmann, Protokolle, 129-133; Grohmann, From the World, 116-118.

64 Grohmann, Protokolle, 118, no. 13 o.

65 Diem, "Einige frühe amtliche Urkunden," 126-130; Grohmann, Protokolle, 130.
} 
Al-Kindī was a highly esteemed historian not only because of his reliability, but also for his accuracy and trustworthiness owing to the fact that he based his work on oral traditions handed down to him through a series of transmitters together with the written records and the archival materials that were available to him. ${ }^{66}$ Nevertheless, a number of governors dropped out of his list. It is remarkable that all those governors are from the Abbasid era, the period for which there is in general a considerable discrepancy in dates and names in al-Kindi's history when compared with documentary evidence or other later sources. ${ }^{67}$ The present papyri are therefore of special interest as they form an important addition and check on contemporaneous historical records. In addition they produce valuable information about the history of the administration of Egypt under Arab rule and complete in the best possible way the data furnished by the historians.

Finally, these documents show not only that people in the countryside knew who the governors and financial directors were but also that authority was imposed by mentioning such governors and financial directors. Moreover, this article shows how papyri, although mostly found in the countryside, can offer very detailed information about the competence of governmental officials like governors and their subordonates in the capital. In order to fully understand the complex administrative apparatus of early Islamic Egypt, we should look into the history of the whole area where its authority was spreading, meaning mainly the Egyptian countryside where extensive correspondence with officials and locals had to be maintained for efficient management of the province.

\section{Acknowledgements}

I would like to thank Petra Sijpesteijn, Marie Legendre and Jelle Bruning for reading and commenting on earlier drafts of this article and for checking my English. I also benefited from the suggestions of Alain Delattre and Sobhi Bouderbala. I am also grateful to the two anonymous reviewers for their suggestions. Any remaining mistakes are, of course, entirely my own.

66 Wadād al-Qāḍī, "An Umayyad Papyrus in al-Kindī’s Kitāb al-Quḍāt," Der Islam 84 (2008): 200-245.

67 Grohmann, Protokolle, 119-121; Kennedy, “Central Government," 33, n. 46. 


\section{Bibliography}

\section{Primary Sources}

al-Dhahabī, Shams al-Dīn Abū 'Abd Allāh Muhammad b. Aḥmad. al-Mushtabih fí alrijäl. Edited by P. de Jong. Leiden: Brill, 1893 .

Ibn 'Abd al-Ḥakam, 'Abd al-Rahmān b. 'Abd Allāh. Futūḥ Mișr wa akhbaruhā. Edited by Charles Torrey as The History of the Conquests of Egypt. Leiden: Brill, 1920.

Ibn al-Athīr, 'Alī b. Muhạmmad. al-Kāmil fi al-tārīkh. Edited by 'Abd Allāh al-Qāạī. 11 vols. Beirut: Dār al-kutub al-ilmiyya, 1987.

Ibn al-Jīān, Sharaf al-Dīn Yahyā b. al-Maqarr. al-Tuhfa al-sanīya bi-asmǟ al-bilād almișriyya. Edited by Bernhard Moritz. Cairo: al-Mațbaca al-ahliyya, 1898.

Ibn al-Kalbī, Abū al-Munzir Hishām b. Muhammad. Nasb Ma'ad wa-l-Yaman al-kabìr. Edited by Nājī Ḥasan. Beirut: Maktabat al-nahḍa al-'arabiyya, 1988.

Ibn Duqmāq, Ibrāhīm b. Muḥammad. al-Intișār li-wāsațat 'aqd al-amașār. Beirut: alMaktab al-tujārī li-l-țiba'a wa-l-tawzī‘ wa-l-nashr, n.d.

Ibn Kathīr, Ismā̄îl b. 'Umar. al-Bidāya wa-l-nihāya. Edited by 'Abd Allāh al-Turkī. 21 vols. Cairo: Dār hajr, 1997.

Ibn Khayyāt, Abū 'Amr Khalīfa b. Khayyāṭ. Tārīkh Khalīfa b. Khayyāț. Edited by Muștafa N. Fawāz and Ḥikmat K. Fawāz. Beirut: Dār al-kutub al-ilmiyya, 1995.

Ibn Mākūla, al-Hāfiz b. Mākūla. al-Ikmāl fì raf' al-irtiyāo 'an al-mu'talaf wa-l-mukhtalaf fí al-asmä’ wa-l-kunā wa-l-ansāb. Edited by 'Abd al-Raḥmān Y. al-Ma'amī. 10 vols. Cairo: Dār al-kitāb al-islāmī, 1993.

Ibn Mammātī, As'd b. Mammātī. Kìtāb qawānīn al-dawāwinn. Edited by 'Azīz S. 'Ațīya. Cairo: Maktabat madbūlī, 1991.

Ibn Manzūur, Muhammad b. Mukarram. Lisān al-'arab. Edited by 'Abd Allāh 'A. al-Kabīr et al. 2 vols. Cairo: Dār al-ma‘ārif, n.d.

Ibn Yūnus, Abū Saīì 'Abd al-Raḥmān b. Aḥmad. Tārīkh Ibn Yūnus al-Mișrī. Edited by 'Abd al-Fattāh 'Abd al-Fattāh. 2 vols. Beirut: Dār al-kutub al--ilmiyya, 2000.

al-Jahshiyārī, Abū 'Abd Allāh Muḥammad b. 'Abdūs. Kitāa al-wūzarā’ wa-l-kuttāb. Edited by 'Abd Allāh al-Ṣāwī. Baghdad: Al-Maktaba al-'arabiyya, 1938.

al-Maqrīzī, Taqiyy al-Dīn Aḥmad b. 'Alī. al-Muqaffã al-kabìr. Edited by Muḥammad alYa'lāwī. 8 vols. Beirut: Dār al-gharb al-islāmī, 1991.

al-Ṭabarī, Muhammad b. Jarīr. Tārīkh al-Rusulwa-l-Mulūk. Edited by Muḥammad Ibrāhīm. 11 vols. Cairo: Dār al-Macārif, 1969 .

Yāqūt al-Ḥamawī, Shihāb al-Dīn Yāqūt b. Abd Allāh. Mújam al-buldān. 5 vols. Beirut: Dār șādir, 1977.

\section{Secondary Sources}

Abbott, Nabia. The Kurrah Papyri from Aphrodito in the Oriental Institute. Studies in Ancient Oriental Civilisation 15. Chicago: Chicago University Press, 1938. 
Abū Șafiyya, Jāsir. Bardiyyāt Qurra b. Sharīk al-'Absī. Riyadh: Markaz al-malik Fayșal lil-buhūth wa-l-dirāsāt al-islamiyya, 2004.

Balog, Paul. Umayyad, 'Abbāsìd and Tūlūnìd Glass Weights and Vessel Stamps. New York: American Numismatic Society, 1976.

Becker, Carl H. “Arabische papyri des Aphroditofundes." Zeitschrift für Assyriologie und verwandte Gebiete 20 (1907): 68-104.

Bouderbala, Sobhi. “Ğund Miṣr: Étude de l'administration militaire dans l'Égypte des débuts de l'islam 21/642-218/833." PhD diss., Université de Paris 1-Panthéon-Sorbonne, 2008.

Bruijn, J.T.P. de. “Kahramān." In Encyclopaedia of Islam, 2nd edition, vol. 4. Edited by P. Bearman, Th. Bianquis, C.E. Bosworth, E. van Donzel, and W.P. Heinrichs, 444445. Leiden: Brill, 1978.

David-Weill, Jean. "Papyrus Arabes du Louvre II." Journal of the Economic and Social History of the Orient 14 (1971): 1-24.

Diem, Werner. "Einige frühe amtliche Urkunden aus der Sammlung Papyrus Erzherzog Rainer (Wien)." Le Muséon 97 (1984): 109-158.

Diem, Werner. "Philologisches zu den Khalili-Papyri I." Wiener Zeitschrift für die Kunde des Morgenlandes 83 (1993): 39-81.

Duri, A.A., H.L. Gottschalk, G.S. Colin, A.K.S. Lambton, and A.S. Bazmee Ansari. "Dīwān." In Encyclopaedia of Islam, 2nd edition, vol. 2. Edited by P. Bearman, Th. Bianquis, C.E. Bosworth, E. van Donzel, W.P. Heinrichs, 509. Leiden: Brill, 1965.

Fahmy, 'Abd al-Raḥmān. Șanj al-sikka fi fajr al-islām. Cairo: Maṭba'at dār al-kutub almișriyya, 1957.

Foss, Clive. "Egypt under Mu'āwiya, Part I: Flavius Papas and Upper Egypt." Bulletin of the School of Oriental and African Studies 72 (2009): 1-24.

Frantz-Murphy, Gladys. Arabic Agricultural Leases and Tax Receipts from Egypt. Corpus Papyrorum Raineri 21. Wien: Hollinek, 2001.

Grob, Eva M. Documentary Arabic Private and Business Letters on Papyrus: Form and Function, Content and Context. Berlin/New York: De Gruyter, 2010.

Grohmann, Adolf. Protokolle. [1:] Einleitung und Texte. Mit einer Schrifttafel und vier Abbildungen im Texte. [2:] Tafeln. Corpus Papyrorum Raineri 3.1/2-3. Wien: Burgverlag Ferdinand Zöllner, 1923-1924.

Grohmann, Adolf. “Aperçu de Papyrologie Arabe.” Études de papyrologie 1 (1932): 23-95. Grohmann, Adolf. "Arabische Papyri aus den Staatlichen Museen zu Berlin." Der Islam 22 (1934): 1-68.

Grohmann, Adolf. Arabic Papyri in the Egyptian Library. 6 vols. Cairo: Egyptian Library Press, 1934-1962.

Grohmann, Adolf. From the World of Arabic Papyri. Cairo: Dār al-Ma'āif Press, $195^{2}$.

Grohmann, Adolf. Einführung und Chrestomathie zur arabischen Papyruskunde, vol. 1, Einführung. Prague: Státní Pedagogické Nakladatelství, 1954. 
Grohmann, Adolf. Studien zur historischen Geographie und Verwaltung des mittelalterlichen Ägypten. Vienna: Rudolf M. Rohrer, 1959.

Grohmann, Adolf. Arabische Chronologie: Arabische Papyruskunde. Leiden: Brill, 1966. Hopkins, Simon. Studies in the Grammar of Early Arabic: Based upon Papyri Datable to Before 300 A.H./912 A.D. Oxford: Oxford University Press, 1984.

Kennedy, Hugh. "Central Government and Provincial Élites in the Early 'Abbasid Caliphate." Bulletin of the School of Oriental and African Studies 44 (1981): 26-38.

Kennedy, Hugh. "Egypt as a Province in the Islamic Caliphate." In The Cambridge History of Egypt I: Islamic Egypt 640-1517, edited by Carl Petry, 62-85. Cambridge: Cambridge University Press, 1998.

Khan, Geoffrey. Arabic Papyri: Selected Material from the Khalili Collection. Studies in the Khalili Collection 1. London/Oxford: Nour Foundation in association with Azimuth Editions and Oxford University Press, 1992.

Lane-Poole, Stanley. History of Egypt in the Middle Ages. London: Methuen, 1925.

Miles, George. "Early Islamic Weights and Measures in Muntaza Palace, Alexandria." Journal of the American Research Center in Egypt 3 (1964): 105-113.

Vanthieghem, Naïm. "Le décret: genése d'un genre documentaire au regard de nouveaux papyrus inédits" (forthcoming).

al-Qāḍī, Wadād. "An Umayyad Papyrus in al-Kindī’s Kitāb al-Quḍāt." Der Islam 84 (2008): 200-245.

Rāgib, Yūsuf. "Sauf-Conduits d'Égypte Omeyyade et Abbasside." Annales Islamologiques 31 (1997): 143-168.

Rāgib, Yusūf. "Lettres Arabes I." Annales Islamologiques 14 (1978): 15-35.

Ramzī, Muhammad. al-Q̄amūs al-jughrāfi li-l-bilād al-mișrīya min 'ahd qudamā' al-mișriyyīn ilā sanat 1945. 6 vols. Cairo: al-Hay’a al-mișriyya al-āmma li-l-kitāb, 1994.

Sijpesteijn, Petra M. "New Rule over Old Structures: Egypt after the Muslim Conquest.” In Regime Change in the Ancient Near East and Egypt: From Sargon of Agade to the Seljuks, edited by Harriet Crawford, 183-202. London: British Academy, 2007.

Sijpesteijn, Petra M. "The Archival Mind in Early Islamic Egypt." In From al-Andalus to Khurasan:Documents from the Medieval Muslim World, edited by Petra M. Sijpesteijn, Lennart Sundelin, Sofía Torallas Tovar and Amalia Zomeño, 163-186. Leiden: Brill, 2007 .

Sijpesteijn, Petra M. "Army Economics: An Early Papyrus Letter Related to 'ațā' Payments." In Studies in the Social and Economic History of the Medieval Middle East: Essays in Honour of Avram L. Udovitch, edited by R. Margarati, A. Sabra and Petra M. Sijpesteijn, 245-267. Leiden: Brill, 2011.

Sijpesteijn, Petra M. "Seals and Papyri from Early Islamic Egypt." In Seals and Sealing Practices in the Near East: Developments in Administration and Magic from Prehistory to the Islamic Period, edited by Ilona Regulski, Kim Duistermaat and Peter Verkinderen, 171-182. Louvain: Peeters, 2012. 
Sijpesteijn, Petra M. Shaping a Muslim State: The World of a Mid-Eighth-Century Egyptian Official. Oxford: Oxford University Press, 2013.

Younes, Khaled. "Joy and Sorrow in Early Muslim Egypt: Arabic Papyrus Letters: Text and Context." PhD diss., Leiden University, 2013.

Zambaur, Eduard von. Manuel de généalogie et de chronologie pour l'histoire de l'islam. Hannover: Orientbuchhandlung Heinz Lafaire, 1955. 


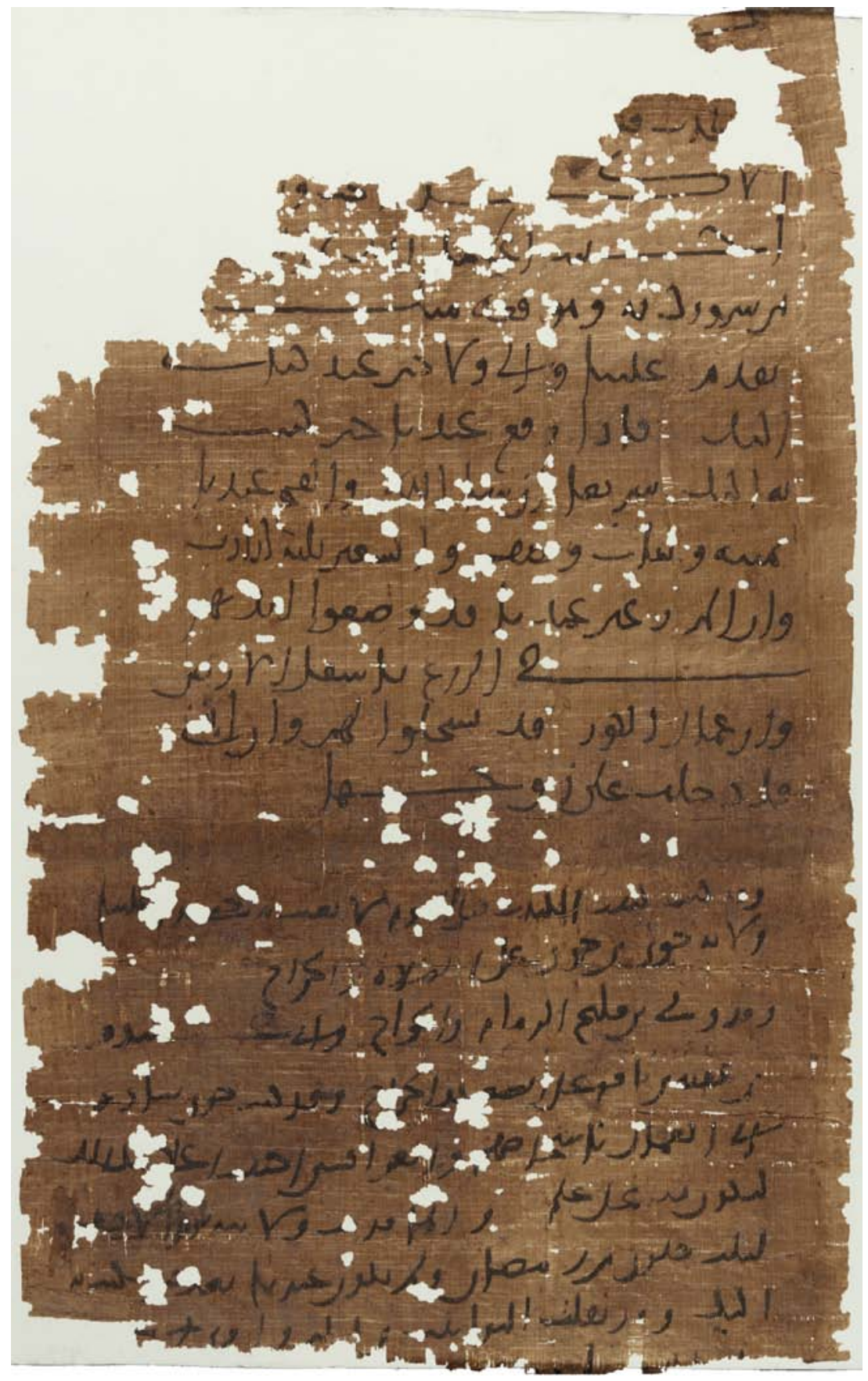

FIGURE 1.1 P.Ryl.Arab B II 10 recto

(C) COPYRIGHT OF THE UNIVERSITY OF MANCHESTER 


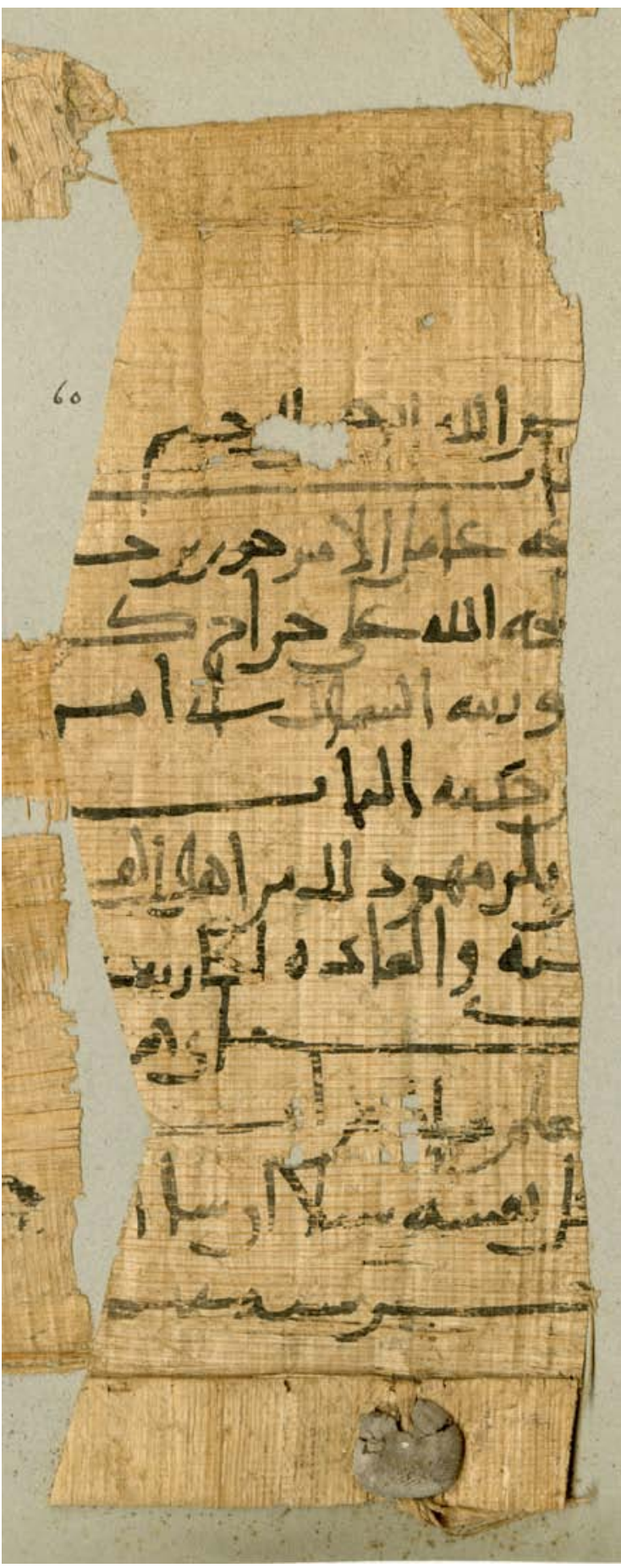

FIGURE 1.2

P.UCL Petrie Ars. inv. 60 (C) DEPARTMENT OF GREEK AND LATIN, UNIVERSITY COLLEGE LONDON 


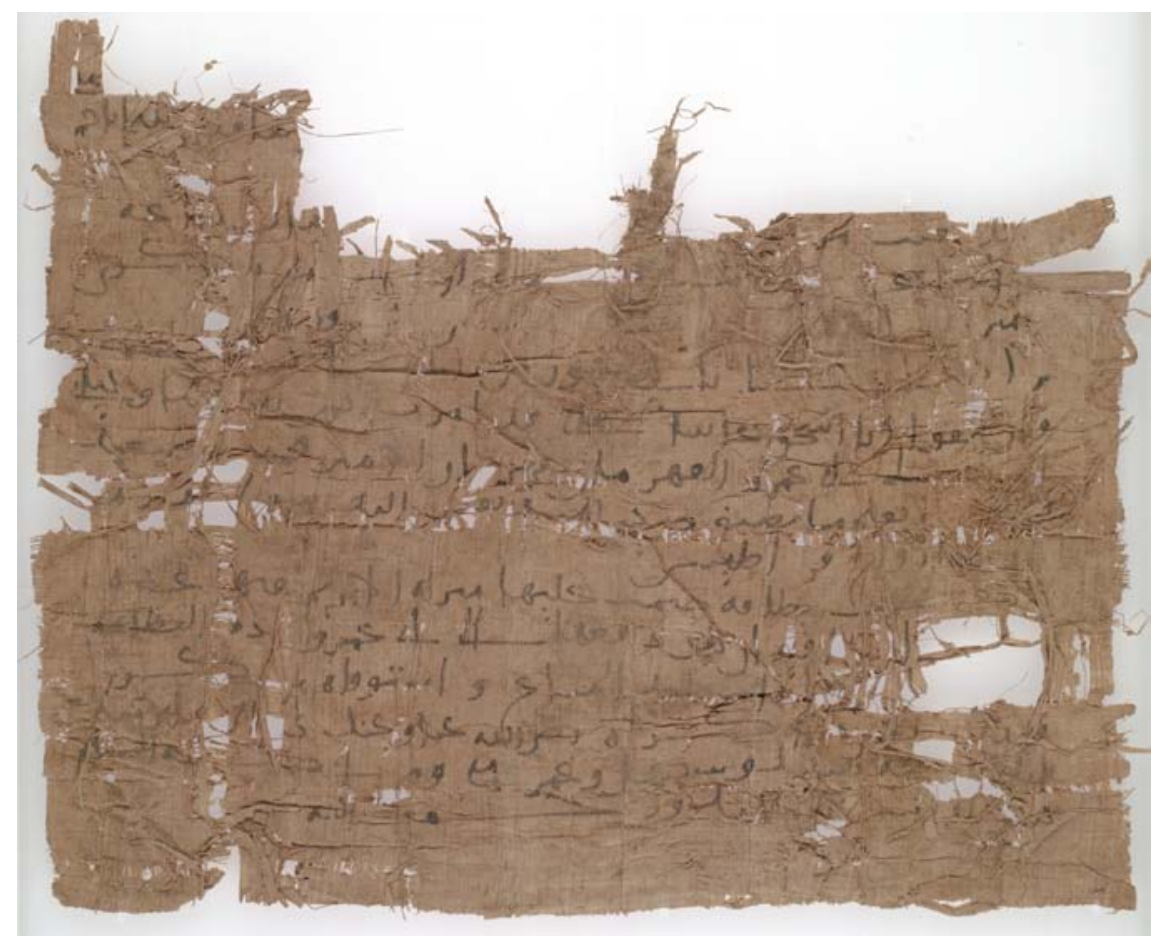

FIGURE 1.3 P.CTYBR. inv. 2733

(C) BEINECKE RARE BOOK AND MANUSCRIPT LIBRARY, YALE UNIVERSITY 